\title{
THE DANIELSON RULE ON THE TAX CONSEQUENCES OF A COVENANT NOT TO COMPETE
}

A covenant not to compete is an agreement by which the promisor pledges not to engage in a certain business activity within a defined area for a specific period of time. ${ }^{1}$ Difficulties frequently arise in adjudging the tax consequences of such an agreement, because it almost always is executed in conjunction with the sale of a business; when the purchase price of the business is in excess of the value of its tangible assets, the difference must be categorized as consideration either for the covenant not to compete or for goodwill. This attribution is critical to the parties. That portion allocated to goodwill is taxable to the vendor as a capital gain and may not be amortized by the vendee, since it is a non-depreciable capital asset. ${ }^{2}$ That portion allocated to the covenant is taxable to the vendor as ordinary income and may be amortized by the vendee, ${ }^{3}$ since it is analogous to payments for services rendered. ${ }^{*}$ Therefore, the vendor generally will seek a small allocation to the covenant in order to preserve capital gains, and the vendee will desire a large allocation which will be amortizable.

The inclusion of a covenant not to compete in the contract for the sale of a business might serve several purposes. The first is the elimination of competition. If that is the primary motive for the sale, the covenant might well represent the essence of the transaction. ${ }^{5}$ Second, the covenant might be necessary to protect the value of a purchased business when a buyer pays more for a going business than the market value of its tangible assets, its worth being increased by such intangibles as goodwill or an ability to generate excess earnings. Since a good portion of this excess worth is attributable to the personalities and efforts of the business' active managers, the purchaser will want assurance that the sellers, if they are the active managers, will not

16 A. Corbin, Contracts \$\$1385-91 (1951).

2 See text accompanying notes 44-45 infra.

3 See Rogers v. United States, 290 F.2d 501 (9th Cir. 1961); Hamlin's Trust v. Commissioner, 209 F.2d 761 (10th Cir. 1954); Cox v. Helvering, 71 F.2d 987 (D.C. Cir. 1934); 3B J. Mertens, Federal Income Taxation $\$ 22.33$, at 217 (rev. ed. 1966).

The general area of the tax effects of covenants not to compete has been the subject of much comment. E.g., Barnet, Covenants Not to Compete: Their Effects Upon the Covenantor and Covenantee, N.Y.U. 18TH INST. ON FED. TAX. 861 (1960); Joseph, Considerations in Applying the Rule of Williams Versus McGowan, 13 TAX L. REv. 369 (1958); Note, The Tax Impact of Covenants Not to Compete Under Current Judicial Concepts, 21 U. of Mranr L. REv. 687 (1967); Note, Tax Treatment of Covenants Not to Compete: $A$ Problem of Purchase Price Allocation, 67 Yale L.J. 1261 (1958).

4 Salvage v. Commissioner, 76 F.2d 112 (2d Cir. 1935), aff'd on other grounds, 297 U.S. 106 (1936) ; Beals' Estate v. Commissioner, 82 F.2d 268 (2d Cir. 1936); Cox v. Helvering, 71 F.2d 987 (D.C. Cir. 1934); see O.D. 668, 3 Cun. Bull. 93 (1920).

5 This is especially true when a service business, such as an insurance agency or a professional practice is being transferred. E.g., Eleanor M. Lutz, 45 T.C. 615 (1966) (insurance agency). 
immediately enter into competition with the transferred enterprise. A third possibility is that the purchaser might want a covenant primarily because of the tax advantage inherent in the right to amortize it against the ordinary income of the business. ${ }^{6}$

There are three factors which should be considered when an attempt is made to determine the proper tax treatment of a covenant transaction. The first is the business consequence of the covenant. If a particular covenant is so worded that it does not significantly restrict the economic activity of the covenantor, ${ }^{7}$ or if the covenantor would not realistically be able to compete with the covenantee under any circumstances, ${ }^{8}$ then the covenant is of little value and entitled to a small consideration.

The second factor involves the interrelationship of the covenant and the other non-tangible business assets. Vendors frequently contend that the worth of a covenant is so intimately related to the worth of the other non-tangible capital assets, particularly goodwill, that it is economically meaningless if considered apart therefrom. ${ }^{9}$ It sometimes has been held that certain covenants are valuable only insofar as they protect the transferred goodwill, and that they therefore produce capital gain for the covenantor and become a non-amortizable capital asset of the covenantee. ${ }^{10}$ Several factors support such a result: (1) even without a covenant, a transferor of goodwill is generally prohibited from subsequently interfering with the transferee's enjoyment thereof; ${ }^{11}$ (2) when both goodwill and a covenant are part of a transaction, it is extremely difficult to estimate with any accuracy the relative value of each; (3) goodwill is usually the more valuable of the two. The major weakness of this position is that a covenant rarely is included in a transaction for any purpose but the protection of "goodwill." Such a pledge can do little to protect the value of the other assets. Given that

6 This is not to suggest that such explicit bargaining for tax benefits is either desirable or permissible, especially when the goals of the bargaining go beyond the minimization of tax burdens and contemplate actual shifting of the tax's incidence. Cf. note 53 infra.

7 See, e.g., Schulz v. Commissioner, 294 F.2d 52 (9th Cir. 1961) (covenantor's activity restricted for one year within one mile area after sale of tool manufacturing partnership).

8 See, e.g., Max J. Epstein, 23 CCH Tax Ct. Mem. 1167 (1964) (covenantor 74 years old and blind).

9 See Barran v. Commissioner, 334 F.2d 58 (5th Cir. 1964) ; Schulz v. Commissioner, 294 F.2d 52 (9th Cir. 1961); Ullman v. Commissioner, 264 F.2d 305 (2d Cir. 1959); Fox \& Hounds, Inc., $21 \mathrm{CCH}$ Tax Ct. Mem. 1216 (1962); Joseph Faulkner, 15 CCH Tax Ct. Mem. 175 (1956); Aaron Michaels, 12 T.C. 17 (1949), acquiesced in, 1941-1 Cum. Bull. 3 ; Taylor, Covenants Not to Compete: Consulting Arrangements, Adjustments to Purchase Price, N.Y.U. 12TH INST. ON FED. TAX. 1047, 1053 (1954); Note, An Inquiry Into the Nature of Goodzvill, 53 Colum. L. REv. 660 (1953).

10 E.g., Fox \& Hounds Inc., 21 CCH Tax Ct. Mem. 1216 (1962) ; Sidney Alper, 15 CCH Tax Ct. Mem. 1415 (1956); Joseph Faulkner, 15 CCH Tax Ct. Mem. 175 (1956); Toledo Newspaper Co., 2 T.C. 794 (1943), acquiesced in, 1944 Cum. Bull. 28.

11 See Note, An Inquiry Into the Nature of Goodwill, 53 Colum. L. Rev. 660, 670-74 (1953). 
covenants are entitled to tax significance when they are enforceable and valuable, it would seem therefore that an effective covenant should be recognized independently if it increases the value of the goodwill by an ascertainable amount.

Assuming the effectiveness and independent significance of a covenant, a third factor is the parties' relative valuation of the covenant. $^{12}$ To guard against careless or manipulative allocations, the accuracy of the valuation should be measured against the result which might be reached by prudent businessmen bargaining at arm's length.

Past judicial attempts to determine the tax results of covenants not to compete have been characterized by a tendency to obscure the distinctions between the component issues of the problem. The courts have relied on several tests, each of which emphasizes one of the above features, but none of which gives a reason for rejecting the other factors pertinent to the inquiry. One of the oldest tests involves an inquiry into the "severability" of the covenant, focusing entirely upon whether the covenant has an ascertainable value apart from the protection of goodwill. ${ }^{14}$ Another test emphasizes the intent of the vendor and vendee. ${ }^{15}$ As with most intent standards, however, use of this criterion necessitates lengthy investigation into the past psychological condition of the parties. ${ }^{16}$ Closely related to the intent formula-

12 See, e.g., Fuiton Container Co. v. United States, 355 F.2d 319 (9th Cir. 1966); Levine v. Commissioner, 324 F.2d 298 (3d Cir. 1963); Annabelle Candy Co. v. Commissioner, 314 F.2d 1 (9th Cir. 1962) ; Wilson Athletic Goods Mfg. Co. v. Commissioner, 222 F.2d 355 (7th Cir. 1955) ; Joseph, Considerations in Applying the Rule of Williams Versus McGowen, 13 TAX L. Rev. 369 (1958).

13 See Taylor, Covenants Not to Compete: Consulting Arrangements, Adjustments to Purchase Price, N.Y.U. 12тr INST. on FED. TAX. 1047, 1053 (1954).

14 The "severability" test was rejected in Schulz v. Commissioner, 294 F.2d 52 (9th Cir. 1961) and in Balthrope v. Commissioner, 356 F.2d 28 (5th Cir. 1966), on the ground that it merely rewords the underlying issue.

The method by which ownership of a business is transferred, whether by sale of business assets or by sale of corporate stock, has often been important under this test. Where assets are transferred, the courts have said that since a covenant was probably necessary to protect the goodwill, it thus will have validity only in unusual cases. Where only the stock of the corporation is sold, a covenant is more likely to be seen as having independent validity. This distinction, although possibly spurious when applied to the sale of a close corporation, was used in Balthrope v. Commissioner, id. at 32 (even though the court refused to use the "severability" test) and in Hamlin's Trust v. Commissioner, 209 F.2d 761, 765 (10th Cir. 1954).

15 In Wilson Athletic Goods Mfg. Co. v. Commissioner, 222 F.2d 355 (7th Cir. 1955 ), Wilson claimed that $\$ 132,000$ of the purchase price of a small footwear manufacturing concern was given in consideration for the vendor's covenant not to compete, although there was no allocation in the contract of sale. The Tax Court found against Wilson, but the Seventh Circuit reversed, saying, "Therefore, it was the duty of the tax court and is our duty here to ascertain the true intent, insofar as tax consequences are concerned." Id. at 357.

See Annabelle Candy Co. v. Commissioner, 314 F.2d 1 (9th Cir. 1962) (presence or absence of allocation important as evidence of intent); Glendon Whitmore, 25 CCH Tax Ct. Mem. 1243 (1966).

16 The facts which most frequently have been looked to by courts when dealing with such covenant situations include: (1) whether the covenant was separately bargained for, e.g., Emmette L. Barran, 39 T.C. 515 (1962), aff'd 334 F.2d 58 (5th Cir. 1964); Clarence Clark Hamlin Trust, 19 T.C. 718, 725 (1953), aff'd, 209 F.2d 761 (10th Cir. 1954); Eleanor M. Lutz, 45 T.C. 615 (1966); Howard Constr., Inc., 
tion is the "economic reality" test, ${ }^{17}$ which compares the parties' allocation with that which would have been arrived at by reasonable men in the same position. The use of this measure again involves the court in an extensive examination of the facts, although here the operative criteria are perhaps more open to objective scrutiny. ${ }^{18}$

The courts always have emphasized the presence or absence of a specific allocation of value to the covenant. Attractive in its simplicity and unlike the other tests in that it does not inquire into the substance of the agreement, this factor has been relied on more frequently and with increasing weight in recent opinions. ${ }^{10}$

In applying any of these tests, courts frequently insist that the taxpayer challenging the Commissioner's determination of a covenant's tax consequences produce "strong proof" of his assertion. The proof must be sufficient to overcome the strong presumption of correctness that attaches to the Commissioner's determination of a tax liability. First clearly articulated in Ullman v. Commissioner, ${ }^{20}$ the "strong proof" rule has been cited approvingly in numerous cases since then.21 By addressing itself to the requisite quantity of evidence, the rule has allowed the courts to avoid extensive consideration of the substantive problems in all but the most egregious instances, and also has become

43 T.C. 343 (1964) ; Raymond W. Johnson, 25 CCH Tax Ct. Mem. 198, 203 (1966); John W. Shleppey, 22 CCH Tax Ct. Mem. 793 (1963) (covenant not separately bargained for and allocated value treated as capital gain); (2) whether the parties had competent legal advice, e.g., Levine v. Commissioner, 324 F.2d 298 (3d Cir. 1963); Raymond W. Johnson, supra; (3) if the covenantors were real competitive threats, e.g. Montesi v. Commissioner, 340 F.2d 97 (6th Cir. 1965) (covenantor in fact entered into competition with covenantee after the expiration of a five year covenant, allocation upheld); (4) if the parties knowingly entered into the agreement, e.g., Schulz v. Commissioner, 294 F.2d 52 (9th Cir. 1961) ; Clarence Clark Hamlin Trust, supra; Benjamin Levinson, 45 T.C. 380 (1966).

17 The Ninth Circuit developed the economic reality test in Schulz v. Commissioner, 294 F.2d 52 (9th Cir. 1961). See text accompanying notes 61-62 infra. In that case, the court expressed its agreement with a "strong proof" requirement. Accord, Levine v. Commissioner, 324 F.2d 298 (3d Cir. 1963); Annabelle Candy Co. v. Commissioner, 314 F.2d 1 (9th Cir. 1962). The economic reality test was criticized as simplistic in Barran v. Commissioner, 334 F.2d 58, 63 (5th Cir. 1964).

18 The common factual standards used here include: the nature of the business, its past earnings, the value of the covenant relative to the rest of the purchase price and the potential competitive threat of the covenantors.

19 See Montesi v. Commissioner, 340 F.2d 97 (6th Cir. 1965); Annabelle Candy Co. v. Commissioner, 314 F.2d 1 (9th Cir. 1962); Ullman v. Commissioner, 264 F.2d 305 (2d Cir. 1959); Benjamin Levinson, 45 T.C. 380 (1966); Emmette L. Barran, 39 T.C. 515 (1962), aff'd, 334 F.2d 58 (5th Cir. 1964); Anthony Rock, 21 CCH Tax Ct. Mem. 46 (1962).

20264 F.2d 305 (2d Cir. 1959).

21 For cases in which the court indicated in its opinion that the burden of strong proof had not been fulfilled, see, e.g., Balthrope v. Commissioner, 356 F.2d 28 (5th Cir. 1966); Annabelle Candy Co. v. Commissioner, 314 F.2d 1 (9th Cir. 1962); Benjamin Levinson, 45 T.C. 380 (1966) ; Tobe C. Deutschmann, 25 CCH Tax Ct. Mem. 1188 (1966); Anthony Rock, 21 CCH Tax Ct. Mem. 46 (1962). For cases in which the burden of strong proof was carried, see, e.g., Max J. Epstein, $23 \mathrm{CCH}$ Tax Ct. Mem. 1167 (1964) (covenantor 74 years old and blind, 90 per cent of the purchase price allocated to the covenant); John W. Shleppey, $22 \mathrm{CCH}$ Tax Ct. Mem. 793 (1963) (some overtones of fraud); Sidney Alper, 15 CCH Tax Ct. Mem. 1415 (1956) (covenant not separately bargained for). 
a fundamental judicial tool in covenant cases. ${ }^{22}$ Recently, however, at the urging of the Internal Revenue Service, the Court of Appeals for the Third Circuit adopted an even more rigid rule of proof in Commissioner $v$. Danielson. ${ }^{23}$

In Danielson, the vendor-stockholders of a small loan company challenged a deficiency notice. During the negotiations for the sale of the business, the vendee offered to purchase all of the common stock of the loan company for $\$ 374$ per share and "our usual non-compete agreement in the Butler area." ${ }^{24}$ The vendee mentioned that it was able to offer a price in excess of the stock's true market value because that excess was amortizable. ${ }^{25}$ The covenant was not mentioned again until the day of the sale, when the vendee suggested allocating $\$ 152$ of the $\$ 374$ per share price to the covenant. The vendors questioned the tax treatment which they would receive on the $\$ 152$ and the vendee explained that the allocation was to his own benefit, but did not tell the vendors that such amount was taxable to them as ordinary income. ${ }^{28}$ After a brief conversation with their attorney, the vendors signed the agreement of sale containing the allocation.

Each vendor claimed capital gains treatment for all income from the sale; the Commissioner then issued a deficiency notice to all of them. The Tax Court decided in favor of the taxpayers, holding that an examination of the facts showed that the covenant was: (1) not realistically bargained for; (2) meaningless due to the improbability of competition from any of the vendors; ${ }^{27}$ (3) so loosely drawn as to be ineffectual; (4) merely an attempt to transfer the goodwill of the company under another name. ${ }^{28}$ The Third Circuit reversed, announcing a "new rule":

22 See Edward Mathews, 36 T.C. 483 (1961), aff'd, 311 F.2d 795 (3d Cir. 1963); cases cited note 21 supra.

23 378 F.2d 771 (3d Cir. 1967), cert. denied, 88 S. Ct. 94 (1967), rev'g Carl L. Danielson, 44 T.C. 549 (1965) [hereinafter cited as Danielson].

24378 F.2d at 773.

$25 I d$.

$26 I d$.

27 The Tax Court found that:

Thrift [the vendee] ignored entirely the usual ingredients of noncompetition, such as age, previous experience, and likelihood of continued activity in the area. When the agreements were executed, one of the petitioners was a 93-year-old retired businessman who rarely left his home and whose affairs were conducted by his wife. Of the remaining petitioners, three were housewives with no knowledge of the small loan business. Only McLennan and Danielson remain. McLennan was in real estate and insurance work, residing and doing business some 60 miles beyond the area covered in the covenant. Danielson was a busy and successful surgeon. Neither of these men wanted to compete with Thrift in the small loan business in Butler again. But, even assuming their desire to do so, such competition would have obviously taken the form, used by them in Butler Loan, of being stockholders and directors. As previously pointed out, the covenants did not prevent any such threat of competition.

44 T.C. 549,557 (1965).

$28 I d$. 
A party can challenge the tax consequences of his agreement as construed by the Commissioner only by adducing proof which in an action between the parties to the agreement would be admissible to alter that construction or to show its unenforceability because of mistake, undue influence, fraud, duress, etc. ${ }^{29}$

There are two unanswered questions on the face of the new rule: to what specific situations does it apply?; how broad is the avenue of escape left open to the parties? As to the first, the new rule probably applies only to situations where there is a specific allocation of value to the covenant, not to situations where the contract is silent as to allocation. Three factors in the history of Danielson support this conclusion. First, the government's brief limits the applicability of the "new rule" to situations of specific allocation. ${ }^{30}$ Second, the Third Circuit quotes approvingly ${ }^{31}$ from the case of Annabelle Candy Co. v. Commissioner:

In the purchase agreement involved in the case before us, there is no allocation of consideration to the covenant not to compete. While this is pretty good evidence that no such allocation was intended it is not conclusive on the parties as would be the case if there had been an express affirmance or disavowal in the agreement. ${ }^{32}$

29378 F.2d at 775. The cases discussed in Danielson are best described as being neutral in relation to the new rule. Aside from the fact that none of them adopt any "rule" similar to the one established in Danielson, only three of them could be characterized as supporting the reasoning behind the new rule: Annabelle Candy Co. v. Commissioner, 314 F.2d 1 (9th Cir. 1962); Rogers v. United States, 290 F.2d 501 (9th Cir. 1961); Hamlin's Trust v. Commissioner, 209 F.2d 761 (10th Cir. 1954). Further, of the three cases, only Hamlin's Trust contains strong approving language. In Annabelle Candy Co., there was no allocation and the reference to instances of allocation was dictum. Rogers was a per curiam affirmance that went off on the "clearly erroneous" rule in refusing to reverse the district court.

A further problem with these Ninth Circuit cases is that a subsequent decision in that circuit, Yandell v. United States, 315 F.2d 141 (9th Cir. 1963), said, for purposes of that case, "we assume that in order to determine proper payments of income tax the courts may look behind a contract such as this and that its form does not necessarily control." Id. at 142 . The court footnoted this statement by saying,

Nor do we find it necessary to determine the validity of the Government's contention that while the Commissioner. . may look behind the terms of the contract to determine the true nature of the agreement, an individual taxpayer may not do so.

Id. at 142 n.1.

There are two problems with Hamlin's Trust v. Commissioner, supra. First, as was recognized in Danielson, 378 F.2d at 777, the evidence in Hamlin might have required the same result under either the "strong proof" rule or the "new rule." Secondly, the court in Hamlin's Trust went on to consider factors other than the presence of a specific allocation: "Thus it is clear that the covenant not to compete was severable; that the parties dealt with it separately; and that the amount received for it was specified and therefore is ascertainable. Id. at 765. 1967).

30 Brief for Petitioner at 11-14, Danielson v. Commissioner, 378 F.2d 771 (3d Cir. 
Third, the court discusses the new rule primarily in the context of the specific allocation situation. ${ }^{33}$

The second question, however, is more troublesome, since its resolution requires an examination of both the type and quantity of proof necessary to show "mistake, undue influence, fraud, duress, etc." ${ }^{34}$ The difficulty is evident when it is realized that every covenant has two results: the restrictions on the covenantor's freedom of economic action (the business results of the covenant) and the tax treatment of the consideration attributable to the covenant (the tax results). There might be a mistake or fraudulent misrepresentation as to the covenant's business results, tax results or both. ${ }^{35}$ It is fairly clear that a party who could show that he was defrauded or mistaken as to the covenant's business results did not enter into the covenant understandingly and would be released from its obligations. The difficult case concerns the covenantor who was aware of the covenant's business import, but who was defrauded or mistaken as to its tax results. It is quite possible that the Third Circuit meant to limit relief to instances of fraud, mistake, duress or undue influence which went to the business results of the covenant. The court quoted approvingly ${ }^{36}$ from Hamlin's Trust $v$. Commissioner:

It is enough if parties understand the contract and understandingly enter into it . . . . It is reasonably clear that the sellers failed to give consideration to the tax consequences of the provision, but where parties enter into an agreement with a clear understanding of its substance and content, they cannot be heard to say later that they overlooked possible tax consequences. ${ }^{37}$

Another indication of the focus on "business results" can be found in the government's Tax Court brief, which admitted that a case such as John W. Shleppey, ${ }^{38}$ in which there was apparent fraud as to the tax consequences of a covenant, would be decided solely on the basis of the contractual allocation under the new rule. ${ }^{39}$

The most persuasive of the arguments in favor of the "new rule" is the increased ease of administration that will accrue to the

$33378 \mathrm{~F} .2 \mathrm{~d}$ at 777-79. If the rule does exclude cases where there is no allocation, it is easier to justify, for the presence of an allocated amount makes it more probable that the covenant was considered by both parties.

34 Id. at 775.

35 It should be noted that the concepts of duress and undue influence are not susceptable of this analysis. They focus on a wrongful act of one party that results in non-volitional assent by the other party, any such act being sufficient to render the whole transaction void or voidable. See generally 1 A. Corbin, Contracts $\S 6$ (1963); Restatenent of Contracts $\$ 492$ (1932).

36378 F.2d at 778.

37209 F.2d 761, 765 (10th Cir. 1954).

3822 CCH Tax Ct. Mem. 793 (1963).

39 Reply Brief for Respondent at 110-18, Carl L. Danielson, 44 T.C.. 549 (1965). 
Commissioner. In the past, the Commissioner was forced to litigate many covenant cases, simply because the lack of a definite standard encouraged taxpayers to risk such court action. Moreover, the Commissioner frequently was compelled to assess inconsistent deficiencies against the parties to a covenant transaction in order to protect total revenue. ${ }^{40}$ The "new rule" seemingly provides the Treasury with a more efficient system, by allowing it to adopt as conclusive a result agreed to by the private parties.

The Third Circuit also reasoned that allowing a party to vary his tax consequences would be equivalent to permitting a unilateral reformation of the contract; if the Commissioner successfully challenges the other party, this arguably results in the unjust enrichment of the original challenger. ${ }^{41}$ This argument is based on the realization that, in an arm's length bargain, the final purchase price reflects an understanding that the covenant allocation imposes a tax disadvantage on the covenantor and benefits the covenantee. There is some difficulty, however, with this use of the concept of unjust enrichment, since such a situation usually arises only at the direct expense of the other contracting party. ${ }^{42}$. In the instant situation, the injury will be sustained only by virtue of the action of a third party, the Commissioner. The basic position of the Third Circuit nonetheless is sound; a party might well find that he has lost a benefit which he paid to obtain, when the Commissioner acts to protect government revenue after a successful attack by the other party to the contract. Danielson greatly reduces the chances of litigation aimed at revising the parties' bargained agreement.

The Danielson rule also fosters an increased predictability of the tax consequences that will attend the sale of a covenant, at least insofar as tax-conscious parties are concerned. The increased predictability that the contractual allocation will control will encourage parties to engage in thoughtful and knowing bargaining. Thus, the antithetical tax motives of the covenantor and covenantee, ${ }^{43}$ increases the proba-

40 See, e.g., Danielson, 378 F.2d at 773 n.3 (Commissioner "preserved his position" as to covenantee); Coca-Cola Co. v. Commissioner, 369 F.2d 913 (8th Cir. 1966) and William S. Scull, II, $23 \mathrm{CCH}$ Tax Ct. Mem. 224 (1964) (both cases concern the same transaction, the Commissioner taking opposite positions in each action); Toledo Blade v. Commissioner, 180 F.2d 357 (6th Cir.), cert. denied, 340 U.S. 811 (1950) and Toledo Newspaper Co., 2 T.C. 794 (1943), acquiesced in, 1949-2 Cum. Burl. 3 (two cases also forced the Commissioner to take inconsistent positions as to the same transaction).

41378 F.2d at 775.

42 See Restatement of Restitution \$ 1 (1937); Comment, Liability for Legal Expenses Cansed by Tax Claims Inconsistent with the Contract in the Sale of Business, 114 U. PA. L. REv. 760 (1964).

43 This observation was the basis of a theory proposed by Note, Tax Treatment of Covenants Not to Compete: A Problem of Purchase Price Allocation, 67 Yale L.J. 1261 (1958), in which the author espouses the view that because of the antithetical tax desires of buyer and seller, even the Commissioner should not be able to challenge a specific allocation. Id. at 1269-70. 
bility that an allocation represents a compromise satisfactory to the opposing parties.

The major objections to the rule articulated by the Third Circuit are that it ignores the intent of the Internal Revenue Code of 1954 and that it may encourage sharp practices.

Section 1201(b) of the Internal Revenue Code provides for a specific rate of taxation on the long-term capital gains of any taxpayer. ${ }^{44}$ A long-term capital gain is defined as ". . . gain from the sale or exchange of a capital asset held for more than 6 months ...." 45 If a covenant not to compete has no real value, then the sum allocated to it must represent part of the consideration given for something else, most probably a nontangible capital asset such as goodwill. If it was a capital asset that was sold, the value ought to be taxed appropriately. The fact that parties reasonably may be at variance over the correct value of any item of course must be taken into consideration, but, for the purposes of this argument, it is assumed that the valuation of the covenant sometimes can be shown to be patently erroneous. If such is the case, then it is arguable that not only does the Internal Revenue Code require that the tax consequences not be determined solely on the basis of the contractual allocation, but that it imposes a positive duty upon the Commissioner not to do so. This argument is founded on those provisions of the Internal Revenue Code which require the Commissioner to collect the taxes thereby imposed. ${ }^{46}$ These provisions are mandatory and not directive; it is clear that the Commissioner has no discretion thereunder to alter the
44 (b) Other Taxpayers.-If for any taxable year the net long-term capital gain of any taxpayer (other than a corporation) exceeds the net short-term capital loss . . . there is hereby imposed a tax . . . which shall consist of the sum of-(1) a partial tax computed on the taxable income reduced by an amount equal to 50 percent of such excess, at the rate and in the manner as if this subsection had not been enacted, and (2) an amount equal to 25 percent of the excess of the net long-term capital gain over the net short-term capital loss.

INT. REv. CoDE of 1954 \$1201(b).

45 INT. REv. CODE of $1954 \$ 1222(3)$. That goodwill is a capital asset is fairly clear. The reasoning is based primarily on the fact that since goodwill is not depreciable under $\S 167$ it must be within the purview of $\$ 1221$ :

For purposes of this subtitle, the term "capital asset" means property held by the taxpayer . . . but does not include-... (2) property, used in his trade or business, of a character which is subject to the allowance for depreciation provided in section 167...

INT. Rev. Code of 1954 §1221.

"Goodwill is a capital asset and any gains resulting from the sale thereof are capital gains." Rodney B. Horton, 13 T.C. 143, 149 (1949), non-acquiescence, 1949-2 CuMr. Bull. 4. See Aaron Michaels, 12 T.C. 17, 19 (1949), acquiesced in, 1949-1 Cunr. BuLl. 3.

46 INT. REv. CoDE of $1954 \S 6301$ states that "The Secretary or his delegate shall collect the taxes imposed by the internal revenue laws." The Commissioner receives his power through \&7802: "The Commissioner of Internal Revenue shall have such duties and powers as may be prescribed by the Secretary." 
clear intent of any provision of the Act. ${ }^{47}$ If the "new rule" were one in aid of interpretation, providing guidelines for use in attempts to ascertain the substance of the transaction, it would be well within the scope of the Commissioner's power. However, the "new rule," if applied rigorously, cannot be so characterized; it virtually forecloses judicial inquiry at the behest of the taxpayer into the substance of the transaction in question. It would allow an allocation to control, even if there were a clear demonstration of gross overevaluation. ${ }^{48}$ If a covenant can be shown to be a clear sham, the two-rate structure of the statute ought not be vitiated simply because another rule might be administratively more convenient.49

Another form of this argument was expounded by the dissent in Danielson, where it was argued that the incidence of a tax burden must depend on substance, not form..$^{50}$ Although recognition of the fact that most of the covenant cases which support this assertion were in a different procedural posture-the Commissioner challenging the form of the transaction-vitiates some of its force, the weight of the doctrine ought not be disregarded.

The second objection to the consistent enforcement of covenant allocations is the opportunity thereby given tax-knowledgeable parties to engage in sharp practices, as opposed to normal hard bargaining. The dissent in Danielson recognized this lurking danger and argued that

the difficult burden of showing fraud, etc. placed upon the parties by the majority virtually insures that tax knowledgeable buyers will engage in questionable and sharp dealing to

471 Mertens, Federal Income Taxatron $\$ 3.21$, at 41 (1962 ed.) :

Although the Commissioner has authority to issue Regulations for the enforcement of the revenue laws, such authority does not extend to the establishment of rules of substantive law creating presumptions which are out of harmony with the statutory provisions involved.

48 See notes 40-41 supra and accompanying text.

49 Additionally, the "new rule" approach is out of harmony with the prevalent approaches in analogous areas. The courts often have held that the form of a contract to which the taxpayer was a party is not dispositive of the issue of the proper tax liability, even when it is the Commissioner who is relying on the form of the agreement. See, e.g., Helvering v. F. \& R. Lazarus \& Co., 308 U.S. 252 (1939) ; Helvering v. Tex-Penn Oil Company, 300 U.S. 481 (1937) (cash paid to corporation prior to liquidation was not for corporation assets but for individually owned leaseholds of several stockholders); Landa v. Commissioner, 206 F.2d 431 (D.C. Cir. 1953) (payments on note held by ex-wife really alimony payments); Harold W. Cuckler, 39 T.C. 1107 (1963), acquiesced in, 1966-1 CUM. BULL. 2 (sale of corporate asset held to have been only a financing device).

$50378 \mathrm{~F} .2 \mathrm{~d}$ at 779-83. The dissent relies heavily on Bartles v. Birmingham, 332 U.S. 126 (1947) (band leaders were responsible for payment of employer's social security tax, even though their contract with ballroom operators provided that the operator was to be the musician's employer for this purpose, although it can be distinguished on the basis that non-revenue motives might have moved Congress to levy the tax, and that the existence of these motives, such as making the employer aware that he is responsible for the well-being of his employees, might provide the determinative factor. Cf. Danielson, 378 F.2d at 778. However, aside from this range of considerations, Bartles provides strong support for the dissent's viewpoint. 
secure the advantages of such covenants, and the majority's rule will shield their agreements. ${ }^{51}$

Two aspects of the "new rule" can be examined with an eye to mitigating these two major objections. The first consideration is the manner in which the rule is interpreted and applied by the Commissioner and the courts. It must be recognized that the rule is essentially discretionary. The Commissioner may choose to employ the rule to bind the parties by accepting the contractual allocation or he may choose to ignore the parties' agreement and adopt an independent construction. ${ }^{52}$ The Commissioner might exercise this discretion under the "new rule" in three ways: (1) he might adopt all contractual allocations and never make an independent determination; (2) he might challenge contractual allocations only when the total tax revenues would be increased thereby; ${ }^{53}$ or (3) he might rely on the contractual allocation only when he feels that it is probably fair. If the "new rule" is used in the third fashion, primarily as a rule of evidence to insulate the Commissioner from the necessity of litigating spurious or highly conjectural claims, Danielson is least open to objection. Such a policy of selective application would vitiate a primary defect of the rule: its rigorous employment frequently might result in the enforcement of covenant allocations which were totally devoid of economic reality. The fact, however, that the rule was applied in Danielson, where the Tax Court found no "arguable relationship with business reality," 54 indicates that the rule may not be applied in this manner. ${ }^{55}$

The second aspect of the "new rule" that merits consideration is the apparent requirement that a party seeking to challenge the Com-

51378 F.2d at 782.

52 The Commissioner may always challenge the parties' allocation. See Danielson, 378 F.2d at 77475 and cases cited therein.

53 Due to the peculiar offsetting nature of the situations where a covenant is either treated as giving rise to ordinary income or capital gains, the total revenue usually will be affected only slightly. Thus, if the covenant is held to give rise to ordinary income, the government will get a goodly portion of the allocated amount from the covenantor, but this will be offset by the amortization allowed the covenantee. If the covenant is held to give rise to capital gains to the covenantor, the reduction of his tax burden will be offset by the disallowance of amortization by the covenantee. However, if the parties are in significantly different tax brackets or if one party has substantial losses against which to offset the covenant consideration, revenues may be affected substantially by the allocation. See Note, Tax Treatment of Covenants Not to Compete: A Problem of Purchase Price Allocation, 67 YALE L.J. 1261, 1270 n.48 (1958). Query: in a situation where both parties have filed returns consistent with the allocation, may the Commissioner successfully challenge one party and then invoke the Dainielson rule if the other party applies for a refund? It would seem that the choice to disregard the allocation for one party should eliminate the binding effect against the other party.

5444 T.C. $549,563$.

55 For the Commissioner's opinion, see Reply Brief for Respondent at 110-18, Carl L. Danielson, 44 T.C. 549 (1965). (Commissioner admits that case of John W. Shleppey, 22 CCH Tax Ct. Mem. 793 (1963), where 64 per cent of the purchase price was allocated to a covenant not to compete where the covenant had no actual value, would be decided differently under the new rule; that is, the allocation would be enforced.) The Third Circuit, although it nowhere directly addresses itself to the question, seems to assume that the rule will be applied across the board. 
missioner's insistence upon an allocation must adduce proof of "mistake, undue influence, fraud, duress, etc." 56 This speaks to the business results of the covenant. ${ }^{57}$ The difficulty with this requirement is that it establishes a standard largely irrelevant to the potential abuses of a covenant valuation, because a covenant's tax result is usually the central, if not the only, reason for an allocation..$^{58}$ The injustice caused by a covenant will result from the negotiations surrounding the value to be placed upon the provision, not its existence or enforceability. To hinge the outcome of tax litigation on a standard that focuses upon the business aspects of the covenant device would ignore the essence of the disputed valuation.

One way to avoid this difficulty is to read the Danielson rule as allowing a complaining party to alter the Commissioner's determination if he can show "fraud" or "mistake" relating to the tax incidents of the covenant. If this is done, however, these terms ought to be carefully defined in order to avoid the difficulties inherent in the use of contract terminology. For example, considerations such as whether the contract in question is executory or of what remedy is appropriate are not applicable. For purposes of tax litigation, it might even be best to put aside the technical use of the generic terms "fraud" and "mistake" and to examine the relative knowledge and behavior of the negotiating parties.

How might such a modified rule operate in various situations when the Commissioner chooses to accept a contract allocation? If both parties knew the tax consequences of their agreement, the allocation should stand, since both taxpayers had full opportunity to structure the transaction. Similarly, if both parties were ignorant or mistakenly believed that the consideration assigned to the covenant would be treated as capital gains, an accepted allocation would stand. On the other hand, if one party could demonstrate that he was actively defrauded or misled by the other party as to the proper tax consequences, the allocation should be of no effect.

If it is proven that one tax-knowledgeable party was aware that the other party was either ignorant or erroneously informed as to the tax consequences, the allocation would not control. It is in this situation that the modified version of the "new rule" most likely produces a result divergent from that apparently required by the strict Danielson rule. This variance seems less significant, however, if one includes the contract doctrine of unconscionability, ${ }^{59}$ with which this

56378 F.2d at 775.

57 See text accompanying notes 34-39 supra.

58 See George H. Payne, 22 T.C. 526 (1954), acquiesced in, 1954-2 CuM. Bull. 5.

59 UNIFORM COMMERCIAL CODE \$2-302:

Section 2-302. Unconscionable Contract or Clause.

(1) If the court as a matter of law finds the contract or any clause of the contract to have been unconscionable at the time it was. made the court 
result is consistent, within the Third Circuit's conception of "what may loosely be called common law principles" "60 adequate to revise an allocation. If, however, the knowledgeable party was unaware of the other's ignorance or misapprehension, the allocation should stand. No advantage has been taken of the complaining taxpayer, and ignorance alone ought not be sufficient to release him from the binding effect of his allocation. Such an interpretation of the "new rule" would not encourage deficiency challenges, since the moving party would still have the heavy burden of showing that the requisite states of mind existed and that the allocation was unrealistic.

There are essentially three goals which should be furthered by a covenant-tax result rule: (1) minimization of the potential abuse of the covenant device; (2) fulfillment of the purpose and intent of the Internal Revenue Code; (3) maximization of administrative convenience. In view of these goals, the "new rule" is still somewhat deficient, even when modified by the assumptions that the Commissioner will exercise his discretion with an eye toward economic reality and that fraud or mistake running to the tax consequences will be permissible grounds for attack.

Although the rule would probably curb deliberate abuse of the covenant device, it would engender some frustration of the Internal Revenue Code. For instance, when both parties to a covenant are ignorant of its tax consequences, and the Commissioner fails to challenge the allocation, the taxation might well be based on a distorted valuation. Furthermore, the rule potentially diminishes administrative convenience in two ways. First, its application will involve some inquiry into the mental state of the contracting parties; such inquiry is usually difficult for a court, which must reconstruct the situation after-the-fact. Second, much of the Danielson rule's efficacy depends on the assumption that enforcing all allocations will encourage hard bargaining and realistic valuation. This is in contrast with the previous assumption that the threat of having the allocation overturned by either the other party or the Commissioner will act as a substantial check on the unbridled selfinterest of the tax-knowledgeable party. The Danielson assumption seems more vulnerable than the latter, since it is likely that there will be no decrease in the number of tax-ignorant parties, especially in that class of situations most amenable to sharp practices-small businessmen selling out to larger concerns. It seems more reasonable to assume that

may refuse to enforce the contract, or it may enforce the remainder of the contract without the unconscionable clause, or it may so limit the application of any unconscionable clause as to avoid any unconscionable result.

(2) When it is claimed or appears to the court that the contract or any clause thereof may be unconscionable the parties shall be afforded a reasonable opportunity to present evidence as to its commercial setting, purpose, and effect to aid the court in making the determination.

For an extensive analysis of this provision, see Leff, Unconscionability and the Code-The Emperor's New Clause, 115 U. PA. L. REv. 485 (1967).

60378 F.2d at 779. 
tax-knowledgeable parties will learn the limitations placed upon them than that tax-ignorant parties will learn that allocation is binding.

In light of the three goals mentioned above, an acceptable alternative rule of litigation might be based on an economic reality test, such as that employed by the Ninth Circuit in Schulz v. Commissioner:

[T] he covenant must have some independent basis in fact or arguable relationship with business reality such that reasonable men, genuinely concerned with their economic future, might bargain for such an agreement. ${ }^{61}$

Some of the factors which have been considered in the search for economic reality are: whether there was an arm's length bargain; whether the covenant was treated as a separate and distinct item; whether there was an allocation of part of the purchase price to the covenant; whether the covenant was of significant value; whether the covenant was meaningfully restrictive; whether the vendor was actually able to compete in light of such factors as age, occupation, health and business acumen; and what the tax awareness of the objecting party was. ${ }^{62}$

Such a rule might stipulate that a party could challenge and alter the Commissioner's determination of a tax liability growing out of a covenant transaction any time he could demonstrate that the allocation used by the Commissioner, whether based on the contract of the parties or on an independent determination, was not consonant with economic reality. This ability to challenge should be subject to two limitations: the party would have to present strong proof of his assertion, and, if the Commissioner is relying on a contractual allocation, the party could be defeated by a showing that he understood the nature of the tax consequences at the time that he entered into the contract.

This "economic reality" rule seems to fulfill best the three goals previously suggested. It will clearly produce results in harmony with the intent embodied in the Internal Revenue Code to tax according to the business substance of the transaction. It will control abuses by narrowing the possible range of discretionary allocation, through liberalizing the manner by which an unrealistic allocation can be overturned by the other party. The price for these results will be some reduction in administrative convenience. It is arguable, however, that, for the courts, the economic reality rule is a more wieldy tool than even the "modified" Danielson rule; the determinative criteria are more objective and, therefore, more easily ascertained. Such a rule would best balance the antithetical pressures for accuracy of result and economy of administration. 